\title{
Ocular Adnexal Lymphoma pN1 TNM
}

\section{Finding v8}

National Cancer Institute

\section{Source}

National Cancer Institute. Ocular Adnexal Lymphoma pN1 TNM Finding v8. NCI

Thesaurus. Code C140873.

Ocular adnexal lymphoma with involvement of lymph node region or regions draining the ocular adnexal structures and superior to the mediastinum (preauricular, parotid, submandibular, and cervical nodes). (from AJCC 8th Ed.) 